\title{
Effect of the Inclusion of Organic Copper, Manganese, And Zinc in The Diet of Layers on Mineral Excretion, Egg Production, and Eggshell Quality
}

http://dx.doi.org/10.1590/1516-635xSpeciallssue Nutrition-PoultryFeedingAdditives087-092

\section{-Author(s)}

\section{Carvalho LSS}

Rosa DRV'

Litz $\mathrm{FH}^{\prime}$

Fagundes NS"

Fernandes EA"II

DVM, graduate student in Veterinary Science, the School of Veterinary Medicine, Universidade Federal de Uberlândia, Brazil

" DVM, graduate student in Veterinary Medicine, School of Veterinary Medicine and Animal Science, Universidade Estadual Paulista, Brazil

III Professor of the School of Veterinary Medicine, Universidade Federal de Uberlândia, Brazil

\section{Mail Address}

Corresponding author e-mail addres Letícia Souza Carvalho

Rua Iguaçu, 1072, Bairro Umuarama. CEP: 38405-428. Uberlândia - MG - Brasil.

E-mail: leticiasouzavet@hotmail.com

\section{-Keywords}

Chelated minerals, commercial egg production, egg quality.

\section{ABSTRACT}

This study aimed at evaluating the replacement of inorganic copper, manganese, and zinc sources by organic sources in the diet of laying hens during the second laying cycle in trace mineral excretion, egg production, and eggshell quality. Two hundred and fifty 100 -week-old Dekalb hens were distributed according to a completely randomized design into five treatments with five replicates of ten birds each. The control treatment consisted of a basal diet with all trace minerals in the inorganic form. The other treatments consisted of a basal diet with a mixture of the minerals copper, manganese, and zinc in the organic form with concentrations of $100 \%, 90 \%, 80 \%$, and $70 \%$ of the levels of inclusion of inorganic mineral sources in the control treatment. Trace mineral excretion was determined in five layers per treatment by the method of total excreta collection. Excreta trace mineral contents were determined by atomic absorption spectrophotometry. Egg production and eggshell quality were determined by the mass of the eggs and the egg specific gravity, respectively. For all trace minerals examined, the dietary supplementation with organic sources reduced trace mineral excretion compared with the control group, even at $70 \%$ inclusion level, without compromising egg production or eggshell quality. The replacement of the inorganic trace mineral sources by organics source effectively reduced the excretion of copper, manganese, and zinc by laying hens in the second laying cycle.

\section{INTRODUCTION}

Trace minerals are involved in the animals' metabolism as catalytic agents present in all metabolic reactions, and therefore, they are essential for growth, development, and production (Aksu et al., 2012).

Copper is part of blood proteins and it is related to iron metabolism and absorption, oxygen metabolism, collagen and elastin synthesis, bone formation (Uauy et al., 1998), feathers development and coloring (Scheideler, 2008). Manganese and zinc are enzymes cofactors involved in the synthesis of mucopolysaccharides and carbonate, which are essential for eggshell formation and quality (Swiątkiewicz \& Koreleski, 2008).

The main feedstuffs commonly included in layer diets present marginal mineral deficiency. In order to overcome such deficiencies, diets are commonly supplemented with inorganic sources, such as oxide, carbonate, chloride, or sulfate salts. However, due to the $\mathrm{pH}$ changes that naturally occur in the digestive tract of poultry, there may be antagonism and interactions among trace minerals, as well as with other compounds added with the aim of stabilizing the molecule, forming insoluble compounds, and preventing their absorption by the body (Aksu et al., 2012). 
In order to prevent that trace mineral deficiency due to lack of absorption, they are usually added to the diets at levels higher than the animals actual requirements (Aksu et al., 2012), which contributes to increase mineral excretion and may cause environmental pollution (Mohana \& Nys, 1998).

Nutritional changes and precise estimates of the specific requirements for each production stage and the use of more bioavailable trace mineral sources are strategies that can contribute to reduce environmental pollution. Organic trace mineral sources may be an alternative to inorganic sources. Chelated or organic trace minerals do not sufferionic dissociation in the acidic gastric $\mathrm{pH}$, remaining electrically neutral and protected from chemical reactions with other molecules in the intestinal lumen, which optimizes their absorption and increases their bioavailability relative to inorganic sources (Swiątkiewicz et al., 2014), with consequent improvement in performance (Nollet et al., 2007).

Several authors reported egg quality and performance maintenance or improvement with the addition organic trace minerals in the diet of laying hens (Fernandes et al., 2008; Saldanha et al., 2009; Maciel et al., 2010; Gheisari et al., 2011; Sun et al., 2012; Figueiredo Júnior et al., 2013). However, few studies have evaluated their mineral excretion.

Therefore, this study aimed at evaluating the effects of different dietary supplementation levels of organic copper, manganese and zinc on trace mineral excretion, egg production, and eggshell quality of layers in their second laying cycle.

\section{MATERIAL AND METHODS}

The project was approved by the Ethics Committee on the Use of Animals (CEUA) under protocol number $131 / 10$.

In this experiment, 250 Dekalb White layers with 100 weeks of age and in the second laying cycle, derived from a commercial farm, were used. Birds were housed in group cages (five birds per cage) in a conventional open-sided houses, at Glória experimental farm of the Federal University of Uberlândia (UFU), located in Uberlândia, state of Minas Gerais, Brazil. Water was provided ad libitum and each bird consumed, on average, 106 grams of feed daily. A lighting program of 17 hours of natural and artificial light was applied throughout the experimental period.
Birds were distributed according to a completely randomized experimental design, including five treatments with five replicates of ten birds each.

The basal diet was formulated based on sorghum and soybean meal (Table 1).

The inorganic mineral (ITM) treatment, considered as control, consisted of the basal diet and all trace minerals in the form of salts, as provided in the mineral premix. The other treatments consisted of the inclusion in the basal diet of the addition of a mixture of organic trace minerals (copper, iron, manganese and iodine, chelated with amino acid and partially hydrolyzed proteins) replacing 100\% (100\% OTM), 90\% (90\% OTM), $80 \%$ (80\% OTM), or 70\% (70\% OTM) of the inorganic mineral source. The dietary inclusion levels and the calculated values of the trace elements present in the diets are shown in Table 1.

After eight weeks of feeding the experimental diets, all intact eggs from the five treatments were used to determine egg production as egg mass (EM, g/bird/day) and eggshell quality. Eggshell quality was determined as egg specific gravity by immersion of the eggs in salt solutions with different densities (1070, 1075, 1080, 1085 and 1090), as proposed by Hamilton (1982).

Mineral excretion was evaluated by total excreta collection in one layer per replicate (five birds per treatment), which was randomly selected and housed in individual cages. Trays lined with plastic canvas were fitted under to cages to allow excreta collection. Iron oxide at $1 \%$ was added to the diets to identify the first and last day of the 5-day period of collection. Excreta were collected twice a day, placed in duly identified plastic bags, and stored in a freezer. After thawing at room temperature, excreta were homogenized. Samples dried in a forced-ventilation oven at $55^{\circ} \mathrm{C}$ for 72 hours, and then ground in a conventional mill. Samples weighing approximately one gram per replicate were placed in porcelain crucibles and burnt in a muffle at $600^{\circ} \mathrm{C}$ for two hours. The ashes removed from the muffle were cooled in a desiccator, weighed, and diluted in $20 \mathrm{~mL}$ hydrochloric acid at $50 \%$. This solution was filtered through paper filter and transferred to a volumetric flask, to which distilled water was added to reach $100 \mathrm{~mL}$ volume. Copper, manganese, and zinc levels in the solutions read in an atomic absorption spectrophotometer. All analyses were performed in triplicate and in accordance with the methods of the Brazilian Compendium of Animal Nutrition (Sindirações, 2009). 
Table 1 - Ingredients, calculated nutritional levels of the basal diet, and copper, manganese, and zinc inclusion levels and calculated values in the experimental diets.

\begin{tabular}{|c|c|c|c|c|c|c|}
\hline Ingredients (\%) & & & \multicolumn{4}{|c|}{ Composition } \\
\hline Sorghum $8.8 \%$ CP & & & \multicolumn{4}{|c|}{64.28} \\
\hline Soybean meal $46.5 \% C P$ & & & \multicolumn{4}{|c|}{22.39} \\
\hline Limestone & & & \multicolumn{4}{|c|}{9.12} \\
\hline Dicalcium phosphate & & & \multicolumn{4}{|c|}{1.62} \\
\hline Soybean oil & & & \multicolumn{4}{|c|}{1.68} \\
\hline Vitaminpremix ${ }^{1}$ & & & \multicolumn{4}{|c|}{0.40} \\
\hline Salt & & & \multicolumn{4}{|c|}{0.35} \\
\hline DL-Methionine & & & \multicolumn{4}{|c|}{0.103} \\
\hline Mineral Premix ${ }^{2}$ & & & \multicolumn{4}{|c|}{0.05} \\
\hline Carophyll Yellow pigment & & & \multicolumn{4}{|c|}{0.004} \\
\hline Carophyll Red pigment & & & \multicolumn{4}{|c|}{0.0030} \\
\hline TOTAL & & & \multicolumn{4}{|c|}{100.00} \\
\hline Nutrients (\%) & & & \multicolumn{4}{|c|}{ Calculated Values } \\
\hline Crude Protein & & & \multicolumn{4}{|c|}{16.00} \\
\hline Calcium & & & \multicolumn{4}{|c|}{4.00} \\
\hline Available Phosphorus & & & \multicolumn{4}{|c|}{0.40} \\
\hline Sodium & & & \multicolumn{4}{|c|}{0.17} \\
\hline Available Lysine & & & \multicolumn{4}{|c|}{0.70} \\
\hline Available Methionine & & & \multicolumn{4}{|c|}{0.39} \\
\hline Available Methionine+Cystine & & & \multicolumn{4}{|c|}{0.61} \\
\hline Available Threonine & & & \multicolumn{4}{|c|}{0.54} \\
\hline Available Tryptophan & & & \multicolumn{4}{|c|}{0.18} \\
\hline Available Arginine & & & \multicolumn{4}{|c|}{0.95} \\
\hline Metabolizable Energy (kcal) & & & \multicolumn{4}{|c|}{2700} \\
\hline \multicolumn{7}{|c|}{ Trace Mineral Inclusion Levels } \\
\hline Trace minerals (mg/kg) & & $\mathrm{ITM}^{*}$ & $100 \%$ OTM $^{* *}$ & $90 \%$ OTM & $80 \%$ OTM & $70 \%$ OTM \\
\hline $\mathrm{Cu}$ & & 9.00 & 9.00 & 8.10 & 7.20 & 6.30 \\
\hline $\mathrm{Mn}$ & & 60.00 & 60.00 & 54.00 & 48.00 & 42.00 \\
\hline $\mathrm{Zn}$ & & 60.00 & 60.00 & 54.00 & 48.00 & 42.00 \\
\hline \multicolumn{7}{|c|}{ Calculated Values } \\
\hline $\mathrm{Cu}$ & 18.66 & & 18.66 & 17.76 & 86 & 15.96 \\
\hline $\mathrm{Mn}$ & 76.01 & & 76.01 & 70.01 & .01 & 58.01 \\
\hline $\mathrm{Zn}$ & 85.25 & & 85.25 & 79.25 & 25 & 67.25 \\
\hline
\end{tabular}

${ }^{1}$ Composition of vitamin the premix and additives-Guaranteed levels per kg of product: folic acid (min) $125 \mathrm{mcg}$; pantothenic acid (min) 1,610 mg; biotin (min) $3.75 \mathrm{mg}$; choline (min) 52.2 g; niacin (min) 5,000 mg; Vit-A (min) 2,000,000 IU; Vit-B1 (min) 50 mg; Vit-B12 (min) 2,500 mcg;Vit-B2 (min) 750 mg; Vit-B6 (min) 425 mg;Vit-D3 575,000IU;Vit-E (min) 3,750IU; Vit-K3 (min) $250 \mathrm{mg}$; Se (min) 62.5 mg; Halquinol 7,500 mg.

${ }^{2}$ Composition of mineral premix: Guaranteed levels per kg of product: Cu (min) $18 \mathrm{~g}$; Fe (min) 60g; I (min) 2g; Mn (min) 120g; Zn (min) 120g.

ITM*- Inorganic Trace Minerals; OTM** - Organic Trace Minerals.

Data were first tested for residue normality and variance homogeneity using Shapiro-Wilk normality test, and then submitted to variance analysis. The means of the OTM treatments were compared with the control treatment (ITM) by Dunnett's test. The means of the OTM treatments were subjected to linear regression analysis. A 5\% significance level was adopted for the statistical tests, using the software program SAS (Statistical Analysis System) version 9.3 (SAS, 2011).

\section{RESULTS}

The excretion of copper and manganese was linearly reduced when layers were fed any of the diets supplemented with the organic source compared with the control treatment (Table 2). However, zinc excretion was reduced only when OTM zinc was added at levels lower than $100 \%$. The total replacement of inorganic zinc by the organic source resulted in the same zinc excretion level as the control group. 
Table 2 - Excretion (mg/kg) of copper, manganese, and zinc; egg mass (gram of egg/bird/day); and specific gravity of eggs from laying hens in the laying second cycle fed with organic trace minerals.

\begin{tabular}{llllll}
\hline \multicolumn{2}{l}{ Trace Mineral Excretion } & & & \multicolumn{2}{l}{ Egg Production and Eggshell Quality } \\
\hline Treatments & Copper & Manganese & Zinc & Egg Mass & Specific Gravity \\
\hline Control ITM & 20.6033 & 254.7825 & 874.0275 & 57.5220 & 1082.5322 \\
OTM 100\% & $16.4075^{*}$ & $189.5950^{*}$ & 672.6675 & 60.8320 & 1083.8908 \\
OTM 90\% & $16.6500^{*}$ & $163.7250^{*}$ & $579.5125^{*}$ & 61.6471 & 1083.9302 \\
OTM 80\% & $13.2825^{*}$ & $136.1600^{*}$ & $572.6400^{*}$ & 58.0202 & 1083.4908 \\
OTM 70\% & $13.3250^{*}$ & $129.9850^{*}$ & $489.2275^{*}$ & 61.7211 & 1081.5640 \\
\hline CV (\%) & 18.6101 & 28.0712 & 20.0101 & 9.2915 & 0.1421 \\
P value & $<0.0001$ & $<0.0001$ & 0.0084 & 0.7568 & 0.1679 \\
Regression & Linear $^{*}$ & Linear & & 0.7825 & 0.1114 \\
\hline
\end{tabular}

ITM-Inorganic Trace Minerals; OTM-Organic Trace Minerals.

Means followed by * in the same column differ from the control treatment $(P<0.05)$ by Dunnett's test.

${ }^{1 Y}=4.1935+0.12615 \times\left(R^{2}=0.7628\right)$

${ }^{2} Y=-20.5695+2.06395 x\left(R^{2}=0.9451\right)$

$3 Y=104.89825+5.57193 x\left(R^{2}=0.92\right)$

Egg production, represented by egg mass, and eggshell quality, expressed by the shell specific gravity (Table 2), were not influenced by the treatments, even at the lowest inclusion level of the organic trace mineral source.

\section{DISCUSSION}

There was no effect of organic trace mineral supplementation on eggs mass or egg specific gravity. However, the reduced copper and manganese excretion obtained with the replacement of the inorganic by the organic source is a clear indication of the increased bioavailability of organic trace mineral sources.

The results of this study corroborate the findings of Engin et al. (2015), who described reduction of mineral excretion when inorganic trace mineral sources were replaced by organic minerals in layer diets. Those authors also showed higher bioavailability of copper, manganese, zinc, chromium and calcium, as determined by their serum levels in layers fed with diets containing organic trace mineral sources. Leeson \& Caston (2008) observed $66 \%$ and $78 \%$ reductions in the excretion of zinc and manganese, respectively, and no performance changes when feeding layers with trace-mineral proteinates at $20 \%$ of the inorganic TM level, and therefore proposed the supplementation of minimal levels of organic trace minerals as an alternative to reduce trace mineral excretion.

In the study of Gheisari et al. (2010), the replacement of inorganic sources of copper, manganese, and zinc by organic sources at levels from $50 \%$ to $75 \%$ lower than the NRC recommendations were sufficient to maintain the performance and eggshell and albumen quality in layers in their first laying cycle. According to the authors, when the supplementation levels of trace minerals are low or marginal, the substitution of inorganic by organic sources can improve layer performance and reduce the percentage of broken eggs.

The higher bioavailability of organic trace mineral sources compared with inorganic sources promotes high erenzyme activity, as well as higher trace mineral retention (Sun et al., 2012) and lower excretion (Leeson, 2008), even when added to diets at levels below those used for inorganic trace mineral inclusion. This may be explained by the fact that, in addition of the normal ion absorption mechanisms in the intestines, chelated minerals are also absorbed through the same path ways as the organic molecules with which they are complexed, thereby avoiding competition among minerals for the same carrier, and making them more readily transportable and absorbable for subsequent utilization by the body (Kiefer et al., 2005). According to Manangi et al. (2012), the use of organic trace minerals, among other benefits, offers the opportunity to reduce the environmental impact caused by the poultry industry.

The maintenance of performance, even at the lower levels of OTM inclusion observed in the present experiment, indicates two important facts. The first is that, due to their greater bioavailability, OTM sources are more efficient to maintain layer production performance and eggshell quality than ITM sources. The second suggests that commercial layer diets current contain excessive amounts of inorganic trace minerals, which is a cause of concern both in terms of egg production and quality, by triggering 
antagonism between trace minerals and other dietary nutrients, which are equally important for the layer metabolism, and from the environmental point of view, because the excess of trace minerals is excrete in the environment.

Excreta with a high concentration of minerals contaminate the soil, and may result in groundwater contamination (Nollet et al., 2007), especially in intensive poultry production areas (Swiątkiewicz et al., 2014). Soil fertilization with poultry manure usually exceeds zinc (Mohana \& Nys, 1998), iron, copper, and manganese plants requirements (Swiątkiewicz et al., 2014), which may cause ground phytotoxicity. Therefore, the use of more bioavailable trace mineral sources is important both for animal production and the environment.

Genetic improvement has improved the production efficiency of layers; however, research on trace mineralsh as not evolved at the same pace. Leeson \& Caston (2008) pointed to that the low cost of these ingredients in the total diet composition, less than $0.2 \%$, is responsible for the lack of interest of the scientific community on this subject. The authors also highlighted the lack of knowledge of trace minerals availability in the main feedstuffs as the main obstacle to determine appropriate supplementation levels. In a review about this topic, Asku et al. (2012) indicate that the use of organic trace minerals at low levels has become increasingly common, primarily because of their physiological and ecological contribution; however, experimental data on the effects of such low levels on poultry metabolism are still insufficient. Considering the complexity of mineral metabolism, much needs to be investigated in order to determine accurate estimates of trace mineral inclusions appropriate to each stage of the production cycle in order to maintain productivity while reducing environmental impact.

In the present study, the reduced trace mineral excretion and the maintenance of egg production, as determined by egg mass, and of eggshell, as measured by egg specific gravity, even at the lowest organic mineral inclusion levels, indicate that it is possible to reduce the addition of trace minerals in commercial diets without losses to the producer.

\section{CONCLUSION}

The total replacement of inorganic trace mineral sources by organic sources in the layer diets was efficient to reduce trace mineral excretion and did not compromise egg production or eggshell quality.

\section{REFERENCES}

Aksu DS, Aksu T, Özsoy B, Baytok E. The effects of replacing organic with a lower level of organically complexed minerals ( $\mathrm{Cu}, \mathrm{Zn}$ and $\mathrm{Mn}$ ) in broiler diets on lipid peroxidation and antioxidant defense systems. Asian-Australian Journal of Animal Science 2010;8:10661072

Aksu DS, Aksu T, Önel SE. Does inclusion at low levels of organically complexed minerals versus inorganic forms create a weakness in performance or antioxidant defense system in broiler diets? International Journal of Poultry Science 2012;11:666-672.

Ashmead HD, Graff DJ, Ashmead HH. Intestinal absorption of metal ions and chelates. Springfield: Charles C Thomas; 1985. p. 13-26.

Engin Y, Mizrak C, Gültekin M, Atik Z, Tunca M.Effects of Organic and Inorganic Forms of Manganese, Zinc, Copper, and Chromium on Bioavailability of These Minerals and Calcium in Late-Phase Laying Hens. Biological Trace Element Research 2015;167(2):300-307.

Fernandes JIM, Murakami AE, Sakamoto MI, Souza LMG, Malaguido A, Martins EN. Effects of organic mineral dietary supplementation on production performance and egg quality of white layers. Brazilian Journal of Poultry Science 2008;10(1):59-65

Figueiredo Júnior JP, Costa FGP, Givisiez PEN, Lima MR, Silva JHV Figueiredo-Lima DF, Saraiva EP, Santana MHM. Substituição de minerais inorgânicos por orgânicos na alimentação de poedeiras semipesadas. Arquivo Brasileiro de Medicina Veterinária e Zootecnia 2013;65(2):513518 .

Gheisari AA, Sanei A, Samie A, Gheisari MM, Toghyani M. Effect of diets supplemented with different levels of manganese, zinc, and copper from their organic or inorganic sources on egg production and quality characteristics in laying hens. Biological Trace Element Research 2011;142(3):557-571.

Gheisari AA, Sanei A, Alibemani A, Toghyani M, Saeid SE. Substitution of inorganic with organic forms of minerals as an alternative way to reduce their concentrations in diet and excretion in laying hens. $2^{\circ}$ International Conference on Chemical, Biological and Environmental Engineering; 2010; Cairo. Iran. p. 143-145.

Hamilton RGM. Methods and factors that effect the measurement of egg shell quality. Poultry Science 1982;61(10):2022-2039.

Kiefer C. Minerais quelatados na nutrição de aves e suínos. Revista Eletrônica Nutritime 2005;2(3):206-220.

Leeson S. Trace minerals in poultry nutition-2. Copper and zinc - the next pollution frontier. World Poultry 2008;3:15-17

Leeson S, Caston L. Using minimal supplements of trace minerals as a method of reducing trace mineral content of poultry manure. Animal Feed Science and Technology 2008;142:339-347

Maciel MP, Saraiva EP, Aguiar EF, Ribeiro PAR, Passos DP, Silva JB. Effect of using organic microminerals on performance and external quality of eggs of commercial laying hens at the end of laying. Revista Brasileira de Zootecnia2010;39(2):344-348

Manangi MK, Vazquez-Anon M, Richards JD, Carter S, Buresh RE, Christensen KD. Impact of feeding lower levels of chelated trace minerals versus industry levels of inorganic trace minerals on broiler performance, yield, footpad health, and litter mineral concentration. The Journal of Applied Poultry Research 2012;21:881-890.

Mohanna C, Nys Y. Influence of age, sex and cross on body concentrations of trace elements (zinc, iron copper and manganese) in chickens. British Poultry Science 1998;39:536-543. 
NRC- National Research Council. Nutrient requirements of poultry. $9^{\text {th }}$ rev. edn. Washington: National Academy Press; 1994

Nollet L, Van Der Klis, J.D.; Lensing, M.; Spring, P. The effect of replacing inorganic with organic trace minerals in broiler diets on productive performance and mineral excretion. The Journal of Applied Poultry Research 2007;16:592-597.

Saldanha ESPB, Garcia EA, Pizzolante CC, Faittarone BG, Sechinato A, Molino $A B$, Laganá $C$. Effect of organic mineral supplementation on the egg quality of semi-heavy layers in their second cycle of lay. Brazilian Journal of Poultry Science 2009;11(4):241-247.

SAS. SAS/STAT® 9.3 User's guide. Version 9.3. Cary: SAS Institute; 2011.

Scheideler SE. Trace minerals balance in poultry. Proceedings of the Midwest Poultry Federation Convention; 2008; Minnesota. USA. Lincoln: University of Nebraska, Department of Animal Science; 2008.

Sun Q, Guo Y, Li J, Zhang T, Wen J. Effects of methionine hydroxy analog chelated cu/mn/zn on laying performance, egg quality, enzyme activity and mineral retention of laying hens. Japan Poultry Science Association 2012;49(1) 20-25.
Sindicato Nacional da Indústria de Alimentação Animal. Compêndio brasileiro de alimentação animal. São Paulo: SINDERAÇÕES; 2009

Swiatkiewicz S, Koreleski J. The effect of zinc and manganese source in the diet for laying hens on eggshell and bones quality. Veterinarni Medicina 2008:53(10):555-563.

Świątkiewicz S, Arczewska-Włosek A, Józefiak D. The efficacy of organic minerals in poultry nutrition: review and implications of recent studies 2014 World's Poultry Science Journal 2014; 70:475-486.

Swiatkiewicz S, Koreleski J. The effect of zinc and manganese source in the diet for laying hens on eggshell and bones quality. Veterinarni Medicina 2008;53(10):555-563

Uauy R, Olivares M, Gonzalez M. Essentiality of copper in humans. American Journal of Clinical Nutrition 1998;67(Suppl. 5):952-959. 